\title{
Model ABC Multi-Criteria Inventory Classification (MCIC) Menggunakan Pemrograman Linear pada Produk Kimia
}

\author{
ABC Multi-Criteria Inventory Classification (MCIC) Model \\ Using Linear Programming for Chemical Product \\ Eko Pratomo ${ }^{1)}$ \\ 1) Politeknik APP Jakarta, Jl. Timbul No. 34 Jakarta, 12630, Indonesia \\ ${ }^{*}$ Penulis korespondensi : ekopratomo.app@ gmail.com
}

DOI Number : 10.30988/jmil.v3i2.242

\begin{abstract}
In order to maintain their inventory efficiently, enterprises need to prioritize inventory policies considering multiple criteria. A Multi Criteria Inventory Classification (MCIC) is one of the most effective techniques widely used to classify inventory. In this paper, multiple criteria (annual value, lead time, cost per unit) are considered on ABC inventory classification. The aim of this study is classify products considering those multiple criteria. Multiple criteria ABC Classifications methodology developed by Ramanathan-Model and Ng-Model are used and compared with traditional method. Data are collected from annual chemical product transaction on PT XYZ during 2018. In this paper, linear programming method is used to solve ABC MCIC Model. The result of this study show that 12 items (14\%) are identified as Class A, 26 items (30\%) as class B and the remaining 48 items (56\%) as C Class. In our conclution, we propose inventory policies based on the result of the ABC Models.
\end{abstract}

Keywords: ABC Model; MCIC; Traditional Model; Ramanathan-Model; Ng-Model; Linear Programming; Chemical Product.

\begin{abstract}
Abstrak
Dalam mengelola persediaan secara efisien, perusahaan perlu menentukan prioritas pengelolaan persediaan dengan mempertimbangkan beberapa kriteria. Klasifikasi ABC Multi Kriteria (MCIC) merupakan model klasifikasi persediaan barang yang umum digunakan oleh perusahaan dalam mengelola persediaan dalam jumlah besar. Penelitian ini menggunakan multi kriteria berupa nilai total produk, lead time dan biaya per unit. Tujuan penelitian adalah mengelompokan jenis/kelas barang sesuai dengan tingkat kepentingan dengan mempertimbangkan multi kriteria. Metode Multi kriteria yang telah dikembangkan oleh Ramanathan-Model dan Ng-Model dibandingkan dengan hasil klasifikasi Single criteria ABC (Traditional model). Data yang digunakan adalah data tahunan transaksi produk kimia PT XYZ di tahun 2018. Penyelesaian model ABC multi kriteria (MCIC) dengan pemrograman linear. Terdapat 86 items produk kimia yang diklasifikasikan dengan hasil klasifikasi A sejumlah 12 item (14\%), B sejumlah 26 item (30\%) dan item C sejumlah 48 item (56\%). Pada penelitan ini juga disampaikan kebijakan inventory masing-masing kelas berdasarkan hasil klasifikasi ABC model yang telah dilakukan.
\end{abstract}

Kata Kunci: Model ABC; MCIC; Model tradisional; Model Ramanathan; Model Ng; Pemrograman Linear; Produk kimia. 


\section{PENDAHULUAN}

Pada umumnya, perusahaan mengelola barang dalam jumlah besar baik itu bahan baku maupun produk. Pengendalian persediaan merupakan salah satu cara yang digunakan dalam upaya efisiensi. Persediaan dalam jumlah besar sering melibatkan proses administrasi, finansial dan economic of scale dari sarana penyimpanan, transportasi dan material handling [1]. Oleh karena itu, perusahaan melakukan pengelompokan barang sesuai dengan tingkat kepentingannya sehingga kebijakan dapat diambil terhadap kelompok barang-barang persediaan tersebut.

Salah satu metode yang umum digunakan dalam pengelompokan barang persediaan sesuai kepentingan adalah metode Klasifikasi ABC. Perusahaan menggunakan klasifikasi ABC analisis dengan menetapkan jenis barang ke dalam salah satu dari tiga kriteria yaitu A, B atau C [2]. Kelas A dikategorikan sebagai barang yang sangat penting bagi perusahaan, sementara kelas B merupakan barang dengan kepentingan sedang dan kelas $\mathrm{C}$ dengan kepentingan paling rendah [3]. Masing - masing dapat ditangani secara berbeda-beda dimana pengendalian persediaan terhadap barang dengan kategori A lebih diprioritaskan dibandingkan dengan kategori B [4]. Kategori A merupakan barang yang sangat penting sehingga pihak manajemen akan memberikan perhatian yang lebih besar [5]. Hal ini wajar dilakukan karena nilai total barang tersebut memiliki porsi sangat besar bagi pengeluaran perusahaan.

Metode klasifikasi inventori menggunakan single dan multiple kriteria pada dasarnya dapat dibedakan menjadi dua kategori yaitu metode optimalisasi dan non optimalisasi. Metode optimalisasi dilakukan dengan memaksimasi agregrat skor berdasarkan fungsi objektif (tujuan) [2]. Penentuan klasifikasi berdasarkan peringkat skor yang dihasilkan dari hasil optimalisasi. Metode Ramanathan [6] dan $\mathrm{Ng}$ [7] adalah beberapa metode klasifikasi dengan optimalisasi
Metode Analytic Hierarchy Process (AHP), cluster analysis, decision tree, distance modeling, graphical matrix dan neural network merupakan beberapa contoh yang tidak menggunakan metode optimalisasi [8].

Klasifikasi ABC tradisional mengelompokan kelas barang berdasarkan nilai akumulatif barang tersebut dalam satu tahun. Metode ini mudah digunakan namun dapat menimbulkan inefisiensi pada pengelolaan persediaan [9]. Keputusan yang tidak tepat sering terjadi terhadap nilai total barang yang sangat tinggi namun tidak terlalu kritis terhadap proses bisnis, begitu juga dengan nilai total barang yang tinggi namun memiliki waktu ancangancang (lead time) yang singkat. Resiko kekurangan barang dengan lead time lama lebih besar dibandingkan dengan lead time yang singkat [8]. Dengan demikian, barang dengan lead time lama memiliki kepentingan yang lebih tinggi dibandingkan dengan barang dengan lead time singkat jika dilihat dari resiko kekurangan/ keterlambatan kedatangan barang. Oleh karena itu, metode tradisional dengan hanya mempertimbangkan nilai total barang sebagai kriteria dapat memberikan keputusan yang tidak tepat terhadap klasifikasi barang persediaan.

Multi-Criteria Inventory Classification (MCIC) merupakan metode yang mempertimbangkan beberapa kriteria dalam menentukan kelas barang persediaan. Metode ini dapat memberikan alternatif kriteria dimana kriteria selain nilai total barang juga dianggap penting dalam klasifikasi. Kriteria biaya per unit dan lead time dapat dipertimbangkan sebagai komponen penting dalam penentuan keputusan tersebut.

Beberapa literatur memberikan metode pengelompokan barang persediaan dengan multi-kriteria antara lain dilakukan oleh Ramanathan [6] dan Ng [7]. Model digunakan lebih lanjut oleh Pandya [10], Iqbal [2] dan Serawati [11]. Kiyak [12] menerapkan model $\mathrm{Ng}$ dengan data dari metode Distance Based Consensus yang dikembangkan oleh Bhattacharya [13]. 
Jeddou [14] melakukan study empiris terhadap klasifikasi multi kriteria ABC berupa unit price, lead time, critical of the article dan jumlah klien pada komponen otomotif. Annual cost, critical factor dan replenishment lead time juga digunakan sebagai kriteria dalam study kasus yang dilakukan oleh Lolli [1] dengan metode AHP-K-Veto.

Pada model Ramanathan, kriteria yang digunakan adalah unit cost, annual dollar usage dan lead time sama dengan kriteria yang digunakan pada model $\mathrm{Ng}$. Perbedaan dari dua model ini adalah model penyelesaiannya. Model Ramanathan menggunakan skor masing masing kriteria yang didapat dengan maksimasi multiplier Data Envelope Analysis (DEA) menggunakan metode pemrograman linear. Model Ng menggunakan maksimasi DEA dengan menggunakan bobot variabel endogenous dengan klasifikasi dari nilai partial average.

Klasifikasi persediaan ABC dapat memberikan manfaat seperti mengendalikan dead stock, pembelian, pengelolaan space gudang, pemantauan jumlah persediaan secara efisien dan pengendalian lead time [15].

Pada paper ini disajikan penghitungan klasifikasi ABC baik itu dengan single kriteria (tradisional), model Ramanathan dan model Ng. Data yang digunakan adalah data transaksi selama kurun waktu setahun (2018) pada PT XYZ. Jumlah transaksi yang diolah sebanyak 10.048 transaksi untuk 86 jenis produk kimia yang digunakan untuk menentukan nilai lead time, biaya per unit dan total nilai produk. PT XYZ adalah distributor dan importir utama produk kimia sebagai bahan baku industri manufaktur.

\section{METODE PENELITIAN}

\subsection{Model ABC Tradisional}

Model Tradisional ABC menggunakan kriteria total nilai barang (kumulatif penyerapan modal) pada penentuan kelas barang. Model menggunakan prinsip yang dikemukakan oleh Pareto dimana 20\% dari populasi menghasilkan kontribusi $80 \%$ nilai output, $30 \%$ populasi berkontribusi terhadap $15 \%$ nilai output dan $50 \%$ berkontribusi terhadap 5\% output [16]. Pada perkembangannya, konsep ini digunakan dalam pengendalian persediaan dengan mengklasifikasikan barang dari nilai tertinggi ke nilai terendah. Nilai kumulatif penyerapan modal $80 \%$ ditetapkan sebagai kelas A, $15 \%$ sebagai kelas B dan 5\% sebagai kelas C.

\subsection{Model Ramanathan}

Diasumsikan jumlah item barang yang dikelola adalah i dengan kriteria j. Pengelompokan kelas A, B dan C berdasarkan skor performansi masing-masing item. Ukuran kriteria rata-rata item $\left(\mathrm{y}_{\mathrm{ij}}\right)$ dan transformasi nilai kriteria $\mathrm{j}$ untuk item i adalah $\mathrm{x}_{\mathrm{ij}}$. Semua kriteria memiliki kontribusi positif terhadap performansi [5]. Dalam hal ini terdapat tiga kriteria yaitu total nilai barang (annual value), biaya per unit dan lead time. Kontribusi positif berarti semakin tinggi nilai masing-masing kriteria tersebut maka semakin penting bagi pengelolaan persediaan.

Bobot masing-masing kriteria $\left(\mathrm{v}_{\mathrm{ij}}\right)$ diperlukan dalam menyelesaikan model ini. Optimalisasi dilakukan untuk menentukan bobot yang menghasilkan nilai performansi total maksimum dengan fungsi pembatas jumlah skor masing-masing item lebih kecil atau sama dengan 1 (satu) dan bernilai positif. Secara jelas model ini ditunjukan pada persamaan di bawah ini:

$$
\operatorname{Max} \sum_{j=1}^{j=J} v_{m j} x_{m j} ;
$$

Dengan fungsi pembatas:

$$
\begin{aligned}
& \sum_{j=1}^{j=J} v_{m j} x_{n j} \leq 1, \quad n=1,2,3 \ldots . N \\
& v_{m j} \geq 0, \quad j=1,2,3 \ldots . J
\end{aligned}
$$




$$
\begin{aligned}
& x_{i j} \\
& =\frac{y_{i j}-\min _{i=1,2,3 . . I}\left(y_{i j}\right)}{\max _{i=1,2,3 . . I}\left(y_{i j}\right)-\min _{i=1,2,3 . . I}\left(y_{i j}\right)}
\end{aligned}
$$

Skor $S_{\mathrm{ij}}$ dihitung dengan persamaan di bawah:

$$
S_{i j}=v_{m j} x_{i j}
$$

Langkah penyelesaian model sebagai berikut:

a. Menghitung $x_{i j}$ dengan menggunakan persamaan (4)

b. Menentukan fungsi tujuan dengan persamaan (1) nilai $x_{m j}$ diperoleh dari akumulasi nilai $x$ untuk $m$ item

c. Menentukan fungsi pembatas masingmasing item dengan persamaan (2) dan fungsi pembatas bobot $v_{m j}$ pada persamaan (3)

d. Melakukan optimalisasi persamaan (1) dengan fungsi pembatas (2) dan (3).

e. Menghitung skor masing - masing item dengan persamaan (5) dengan bobot $v_{m j}$ yang menghasilkan fungsi tujuan (1) maksimal

f. Menyusun peringkat skor pada huruf e mulai dari yang terbesar sampai terkecil untuk menentukan kelas A, B atau C

Model tersebut memiliki satu fungsi tujuan dan beberapa fungsi pembatas yang bersifat linear. Dengan demikian, untuk menyelesaikan model tersebut, dapat digunakan metode penyelesaian pemrograman linear.

\subsection{Model Ng}

Pada Model Ng, klasifikasi penentuan kelas barang berdasarkan skor tertinggi variable endogen. Masing-masing kriteria $\mathrm{j}$ pada item $\mathrm{i}$ ditentukan skor kriteria variable $\mathrm{j}$ item $\mathrm{i}$ dihitung dengan menggunakan skala pengukuran dari nilai terbesar sampai nilai terkecil. Persamaan untuk menghitung skor variable j sama dengan persamaan (4) pada model Ramanathan. Model ini dibangun dengan beberapa persamaan sebagai berikut:

$$
\begin{gathered}
\sum_{j=1}^{j=J} w_{i j} y_{i j}=\sum_{j=1}^{j=J} u_{i j} x_{i j} \\
\sum_{j=1}^{j=J} w_{i j}=1, \quad j=1,2,3 \ldots J(7) \\
U_{i j}=w_{i j}-w_{i(j+1)} \geq 0, \quad j=1,2,3 \ldots J
\end{gathered}
$$

dimana $U_{i j}=w_{i J}$

Persamaan (7) dan (8) secara simultan dapat disederhanakan menjadi persamaan (9) sebagai berikut:

$$
\sum_{j=1}^{j=J} j u_{i j}=1, \quad i=1,2,3 \ldots . I
$$

maka fungsi tujuan adalah:

$$
\operatorname{Max} S=\sum_{j=1}^{j=J} u_{i j} x_{i j}
$$

dengan fungsi pembatas:

$$
\begin{gathered}
\sum_{j=1}^{j=J} j u_{i j}=1, \quad i=1,2,3 \ldots . I \\
\text { dengan } U_{i j} \geq 0
\end{gathered}
$$

Penyelesaian persamaan di atas bersifat linear programing dengan fungsi pembatas (10) maka akan dihasilkan solusi optimal untuk satu variable $u_{i j}$ dan variable yang lain bernilai nol. Sehingga untuk mendapatkan nilai $\mathrm{S}$ maksimal dapat ditentukan dengan partial average $x_{i j}$ :

$$
\operatorname{Max}_{j=1,2 \ldots J}\left(\frac{1}{j} x_{i j}\right)
$$

Untuk menyelesaikan proses klasifikasi ABC model $\mathrm{Ng}$ dapat disederhanakan dengan langkah - langkah sebagai berikut:

a. Menghitung $x_{i j}$ dengan persamaan (4) 
b. Menghitung nilai partial average dengan persamaan $\frac{1}{j} \sum_{k=1}^{k=j} x_{i j}$ untuk masing masing item

c. Menentukan nilai average item i dengan nilai terbesar sebagai skor $\mathrm{Si}$

d. Menyusun urutan skor Si dari nilai terbesar ke terkecil

e. Mengelompokan skor Si ke dalam kelas $\mathrm{ABC}$.

\subsection{Diagram alir klasifikasi ABC}

Langkah penyelesaian klasifikasi ABC dengan menggunakan model Ramanathan dan model $\mathrm{Ng}$ sebagaimana ditunjukan pada gambar 1.

Index:

$i, j=\operatorname{item}(i)$ kriteria $(j)$

$j=1$ untuk kriteria annual value

$j=2$ untuk kriteria biaya per unit

$j=3$ untuk kriteria Lead Time

\section{Notasi:}

$y_{i j}=$ nilai kriteria item (i), kriteria (j)

$x_{i j}=$ nilai transformasi item (i) kriteria $(j)$

$v_{m j}=$ bobot item ke $(m)$ kriteria $(j)$

$S_{i j}=\operatorname{skor} i \operatorname{item}(i) \operatorname{kriteria}(j)$

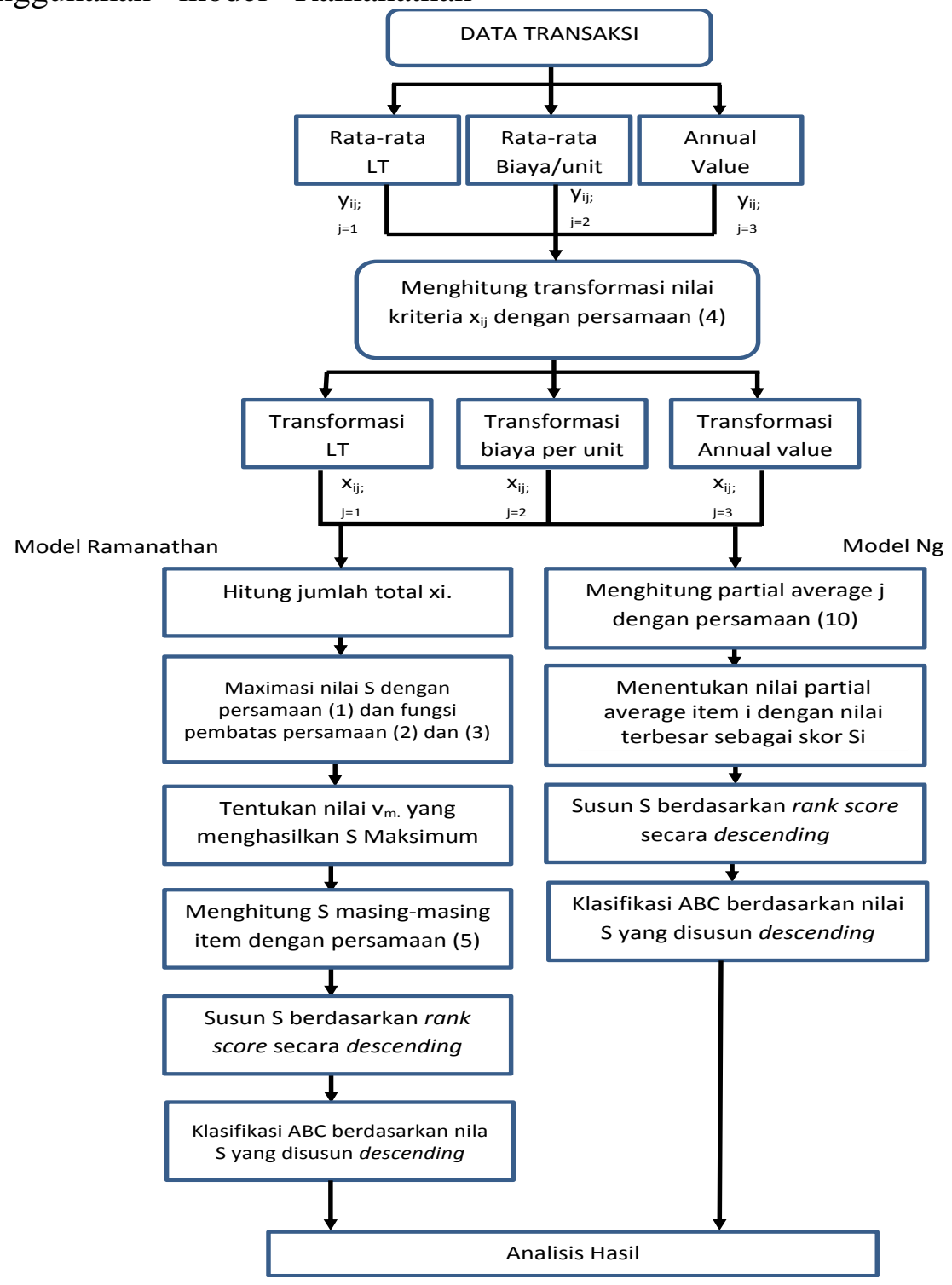

Gambar 1. Diagram Alir Penyelesaian Model 


\section{HASIL PEMBAHASAN}

\subsection{Data Penelitian}

Data yang digunakan dalam penelitian ini adalah data transaksi produk kimia PT XYZ selama kurun waktu 2018. Data yang terkumpul sejumlah 10.048 transaksi selanjutnya dikelompokan dalam 86 item produk kimia.

Lead time dihitung berdasarkan rata - rata waktu yang dibutuhkan setiap produk mulai dari penerbitan PO sampai dengan produk diterima di PT XYZ. Biaya per unit dihitung dari rata - rata biaya per unit produk. Annual value diperoleh dari total pembelian untuk masing-masing item pada tahun 2018. Data rekapitulasi transaksi produk tahun 2018 sebagaimana ditunjukan pada tabel 1.

\subsection{Model Klasifikasi ABC Tradisional}

Pada model penentuan klasifikasi ABC, kriteria yang digunakan adalah nilai total produk dalam satu tahun atau annual value. Dalam perhitungan ini, nilai annual value dihitung dari jumlah produk yang dibeli dalam satu tahun dikalikan dengan harga barang per unit.

Pada proses klasifikasi ABC tradisional, diagram pareto dapat digunakan sebagai acuan pengelompokan barang kelas A, B atau C. Tujuan Diagram Pareto adalah memetakan akumulasi jenis item yang dikelola dalam persediaan dengan nilai kumulatif penyerapan modal.

Menurut Ramanthan dan Flores dasar klasifikasi ABC Tradisional adalah menggunakan prinsip Pareto dimana 80 porsi penyerapan modal merupakan kontribusi dari $20 \%$ item produk yang dikelola. Kelompok produk yang memiliki nilai $80 \%$ dari total nilai seluruh produk dikelompokan ke dalam kelas A, sedangkan kelompok produk yang memiliki nilai akumulatif $15 \%$ dikelompokan ke dalam kelas B dan sisanya 5\% dikelompokan ke dalam kelas C. Urutan pengelompokan didasarkan pada nilai kelompok barang tertinggi ke terendah.

Hasil pengelompokan dengan model klasifikasi ABC Tradisional, sebagaimana ditunjukan pada gambar 2, didapatkan kelompok produk kelas A memiliki porsi annual value sebesar $81,49 \%$ atau $\mathrm{Rp}$. 36.629.290.000, kelas B dengan porsi annual value sebesar $13,75 \%$ atau $\mathrm{Rp}$. 6.180.784.225 dan kelas C sebesar 4,75\% dengan nilai kumulalatif Rp. 2.136.194.800.

Tabel 1. Data nilai kriteria item produk

\begin{tabular}{|c|c|c|c|c|c|}
\hline $\begin{array}{l}\text { Kode } \\
\text { Item }\end{array}$ & $\begin{array}{c}\text { Annual } \\
\text { value } \\
\text { (Rp. ribu) }\end{array}$ & $\begin{array}{c}\text { Cost/unit } \\
\text { (Rp) }\end{array}$ & $\begin{array}{l}\text { LT } \\
\text { (day) }\end{array}$ & $\begin{array}{c}\% \\
\text { Cumm } \\
\text { ulative }\end{array}$ & Kelas \\
\hline PRE1 & 18.043 .226 & 253.640 & 61 & 40,1440 & A \\
\hline PRE2 & 7.827.558 & 282.702 & 61 & 57,5594 & A \\
\hline PRE3 & 3.678 .559 & 256.135 & 85 & 65,7437 & A \\
\hline PRE4 & 3.050 .815 & 265.065 & 40 & 72,5314 & A \\
\hline PRE5 & 2.495 .040 & 298.305 & 42 & 78,0826 & A \\
\hline PRE6 & 1.534 .092 & 756.956 & 50 & 81,4957 & A \\
\hline PRE7 & 732.298 & 1.550 .166 & 162 & 83,1250 & B \\
\hline PRE8 & 643.388 & 754.604 & 124 & 84,5565 & B \\
\hline PRE9 & 641.232 & 357.268 & 40 & 85,9831 & B \\
\hline PRE10 & 561.117 & 565.552 & 51 & 87,2315 & B \\
\hline PRE11 & 512.616 & 1.417 .035 & 23 & 88,3721 & B \\
\hline PRE12 & 364.771 & 1.594 .054 & 137 & 89,1836 & B \\
\hline PRE13 & 359.640 & 579.496 & 45 & 89,9838 & B \\
\hline PRE14 & 347.804 & 2.232 .115 & 53 & 90,7576 & B \\
\hline PRE15 & 337.425 & 1.020 .430 & 168 & 91,5083 & B \\
\hline PRE16 & 336.224 & 363.709 & 93 & 92,2564 & B \\
\hline PRE17 & 321.024 & 1.543 .708 & 32 & 92,9706 & B \\
\hline PRE18 & 247.690 & 236.907 & 82 & 93,5217 & B \\
\hline PRE19 & 226.531 & 3.948 .035 & 74 & 94,0257 & B \\
\hline PRE20 & 199.586 & 934.562 & 74 & 94,4698 & B \\
\hline PRE21 & 176.645 & 1.678 .308 & 19 & 94,8628 & B \\
\hline PRE22 & 172.794 & 503.609 & 94 & 95,2472 & B \\
\hline PRE23 & 164.754 & 604.155 & 15 & 95,6138 & $\mathrm{C}$ \\
\hline PRE24 & 130.356 & 1.869 .655 & 68 & 95,9038 & $\mathrm{C}$ \\
\hline PRE25 & 122.460 & 2.160 .256 & 113 & 96,1763 & $\mathrm{C}$ \\
\hline PRE26 & 120.528 & 1.296 .715 & 30 & 96,4444 & $\mathrm{C}$ \\
\hline PRE27 & 113.399 & 446.805 & 119 & 96,6967 & $\mathrm{C}$ \\
\hline PRE28 & 89.910 & 833.500 & 295 & 96,8968 & $\mathrm{C}$ \\
\hline PRE29 & 85.746 & 499.206 & 39 & 97,0875 & $\mathrm{C}$ \\
\hline PRE30 & 79.610 & 1.156 .056 & 31 & 97,2647 & $\mathrm{C}$ \\
\hline PRE31 & 71.431 & 1.109 .380 & 66 & 97,4236 & $\mathrm{C}$ \\
\hline PRE32 & 62.130 & 335.250 & 11 & 97,5618 & $\mathrm{C}$ \\
\hline PRE33 & 53.946 & 765.028 & 268 & 97,6818 & $\mathrm{C}$ \\
\hline PRE34 & 51.156 & 230.595 & 66 & 97,7957 & $\mathrm{C}$ \\
\hline PRE35 & 49.980 & 431.834 & 64 & 97,9069 & $\mathrm{C}$ \\
\hline PRE36 & 48.620 & 175.404 & 199 & 98,0150 & $\mathrm{C}$ \\
\hline PRE37 & 47.736 & 475.427 & 75 & 98,1212 & $\mathrm{C}$ \\
\hline PRE38 & 47.410 & 875.083 & 81 & 98,2267 & $\mathrm{C}$ \\
\hline PRE39 & 47.058 & 422.880 & 96 & 98,3314 & $\mathrm{C}$ \\
\hline PRE40 & 45.774 & 1.277 .667 & 15 & 98,4333 & $\mathrm{C}$ \\
\hline PRE41 & 38.544 & 138.123 & 47 & 98,5190 & $\mathrm{C}$ \\
\hline PRE42 & 37.378 & 1.009 .274 & 43 & 98,6022 & $\mathrm{C}$ \\
\hline
\end{tabular}




\begin{tabular}{|c|c|c|c|c|c|}
\hline $\begin{array}{l}\text { Kode } \\
\text { Item }\end{array}$ & $\begin{array}{c}\text { Annual } \\
\text { value } \\
\text { (Rp. ribu) }\end{array}$ & $\begin{array}{c}\text { Cost/unit } \\
\text { (Rp) }\end{array}$ & $\begin{array}{l}\text { LT } \\
\text { (day) }\end{array}$ & $\begin{array}{l}\% \\
\text { Cumm } \\
\text { ulative }\end{array}$ & Kelas \\
\hline PRE43 & 36.861 & 1.945 .891 & 27 & 98,6842 & $\mathrm{C}$ \\
\hline PRE44 & 36.840 & 940.727 & 14 & 98,7662 & $\mathrm{C}$ \\
\hline PRE45 & 34.776 & 371.723 & 162 & 98,8435 & $\mathrm{C}$ \\
\hline PRE46 & 34.056 & 228.393 & 116 & 98,9193 & $\mathrm{C}$ \\
\hline PRE47 & 33.475 & 317.344 & 30 & 98,9938 & $\mathrm{C}$ \\
\hline PRE48 & 32.373 & 312.232 & 6 & 99,0658 & $\mathrm{C}$ \\
\hline PRE49 & 23.976 & 548.046 & 75 & 99,1191 & $\mathrm{C}$ \\
\hline PRE50 & 23.076 & 1.575 .163 & 38 & 99,1705 & $\mathrm{C}$ \\
\hline PRE51 & 23.044 & 1.561 .762 & 67 & 99,2218 & $\mathrm{C}$ \\
\hline PRE52 & 21.560 & 394.172 & 219 & 99,2697 & $\mathrm{C}$ \\
\hline PRE53 & 20.075 & 931.326 & 37 & 99,3144 & $\mathrm{C}$ \\
\hline PRE54 & 19.910 & 513.003 & 11 & 99,3587 & $\mathrm{C}$ \\
\hline PRE55 & 19.845 & 275.363 & 139 & 99,4028 & $\mathrm{C}$ \\
\hline PRE56 & 19.000 & 315.875 & 80 & 99,4451 & $\mathrm{C}$ \\
\hline PRE57 & 18.390 & 318.518 & 55 & 99,4860 & $\mathrm{C}$ \\
\hline PRE58 & 18.095 & 1.490 .280 & 10 & 99,5263 & $\mathrm{C}$ \\
\hline PRE59 & 18.072 & 2.404 .847 & 304 & 99,5665 & $\mathrm{C}$ \\
\hline PRE60 & 15.576 & 789.224 & 4 & 99,6011 & $\mathrm{C}$ \\
\hline PRE61 & 15.188 & 2.286 .440 & 5 & 99,6349 & $\mathrm{C}$ \\
\hline PRE62 & 13.857 & 252.089 & 83 & 99,6658 & $\mathrm{C}$ \\
\hline PRE63 & 11.680 & 684.739 & 36 & 99,6918 & $\mathrm{C}$ \\
\hline PRE64 & 10.470 & 1.493 .787 & 113 & 99,7151 & $\mathrm{C}$ \\
\hline PRE65 & 10.032 & 416.274 & 120 & 99,7374 & $\mathrm{C}$ \\
\hline PRE66 & 9.568 & 630.429 & 26 & 99,7587 & $\mathrm{C}$ \\
\hline PRE67 & 9.514 & 618.667 & 21 & 99,7798 & $\mathrm{C}$ \\
\hline PRE68 & 9.465 & 1.907 .140 & 90 & 99,8009 & $\mathrm{C}$ \\
\hline PRE69 & 8.502 & 452.073 & 29 & 99,8198 & $\mathrm{C}$ \\
\hline PRE70 & 8.224 & 5.253 .773 & 304 & 99,8381 & $\mathrm{C}$ \\
\hline PRE71 & 8.060 & 163.956 & 115 & 99,8560 & $\mathrm{C}$ \\
\hline PRE72 & 7.402 & 1.373 .402 & 16 & 99,8725 & $\mathrm{C}$ \\
\hline PRE73 & 6.846 & 534.434 & 27 & 99,8877 & $\mathrm{C}$ \\
\hline PRE74 & 6.225 & 777.050 & 6 & 99,9016 & $\mathrm{C}$ \\
\hline PRE75 & 5.804 & 1.166 .127 & 94 & 99,9145 & $\mathrm{C}$ \\
\hline PRE76 & 5.782 & 704.554 & 35 & 99,9274 & $\mathrm{C}$ \\
\hline PRE77 & 5.080 & 159.112 & 14 & 99,9387 & $\mathrm{C}$ \\
\hline PRE78 & 5.040 & 384.852 & 17 & 99,9499 & $\mathrm{C}$ \\
\hline PRE79 & 4.896 & 282.556 & 56 & 99,9608 & $\mathrm{C}$ \\
\hline PRE80 & 4.106 & 1.722 .399 & 35 & 99,9699 & $\mathrm{C}$ \\
\hline PRE81 & 3.628 & 521.517 & 83 & 99,9780 & $\mathrm{C}$ \\
\hline PRE82 & 3.425 & 190.301 & 641 & 99,9856 & $\mathrm{C}$ \\
\hline PRE83 & 2.749 & 1.313 .122 & 5 & 99,9917 & $\mathrm{C}$ \\
\hline PRE84 & 1.503 & 193.361 & 42 & 99,9951 & $\mathrm{C}$ \\
\hline PRE85 & 1.223 & 471.703 & 35 & 99,9978 & $\mathrm{C}$ \\
\hline PRE86 & 1.001 & 338.748 & 439 & 100 & $\mathrm{C}$ \\
\hline
\end{tabular}

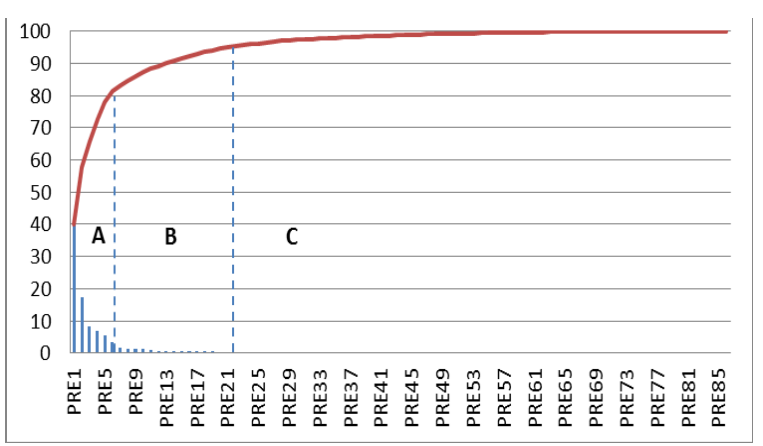

Gambar 2 . Diagram Pareto ABC Tradisional
Dari hasil pengelompokan dengan model ABC tradisional tersebut, kelompok A terdiri dari 6 item, kelompok B sejumlah 16 item dan kelompok C sejumlah 64 item. Selanjutnya, model Ramanathan dan Model $\mathrm{Ng}$ akan dikelompokan dengan distribusi jumlah item dalam kelas sesuai dengan hasil pengelompokan pada model ABC tradisional. Klasifikasi model Ramanathan dan $\mathrm{Ng}$ menghasilkan kelas A sejumlah 6 item, kelas B sejumlah 16 item dan kelas C sejumlah 64 item yang disusun berdasarkan skor tertinggi ke terendah.

\subsection{Model Klasifikasi ABC Ramanathan}

Perhitungan klasifikasi model Ramanathan dimulai dengan menghitung nilai $x_{i j}$ dengan persamaan (4). Misal perhitungan item PRE1:

$$
\begin{aligned}
& y_{12}=253.640 \\
& \operatorname{Min}_{\mathrm{i}=1,2 . . \mathrm{I}\{}\left\{y_{\mathrm{ij}}\right\}=138.123 \\
& \operatorname{Max}_{\mathrm{i}=1,2 . . \mathrm{I}\left\{y_{\mathrm{ij}}\right\}=5.253 .773} \\
& \quad x_{12}=\frac{253.640-138.123}{5.253 .773-138.123}=0.0226
\end{aligned}
$$

Selanjutnya, menghitung bobot $v_{m j}$ yang menghasilkan skor maksimal dengan fungsi tujuan (1) dan fungsi pembatas (2) dan (3):

$$
\begin{aligned}
& \operatorname{Max} \quad \sum_{j=1}^{j=3}\left\{v_{m j} x_{m j}\right\} \\
& \operatorname{Max}\left\{2,486 v_{m 1}+17,736 v_{m 2}+10,812 v_{m 3}\right\}
\end{aligned}
$$

Dengan fungsi pembatas:

$$
\begin{gathered}
1,000 v_{m 1}+0,023 v_{m 2}+0,089 v_{m 3} \leq 1 ; \\
0,001 v_{m 1}+0,010 v_{m 2}+1,000 v_{m 3} \leq 1 ; \\
\vdots \\
0,002 v_{m 1}+0,004 v_{m 2}+0,016 v_{m 3} \leq 1 ;
\end{gathered}
$$

Berdasarkan nilai $v_{m j}$ yang didapat maka dapat dihitung nilai $S_{i \text {. }}$ sebagai skor item untuk menentukan kelas A, B dan C.

Model di atas dapat diselesaikan dengan metode linear programming. Dengan menggunakan software maple 13 didapatkan

$$
\begin{aligned}
& v_{m 1}=0,8996 ; v_{m 2}=0,5313 ; v_{m 2}=0,9945 \\
& \operatorname{Max} \sum_{j=1}^{j=3} v_{m j} x_{m j}=19,7549
\end{aligned}
$$


Hasil perhitungan ditunjukan pada tabel 2

Tabel 2. Hasil Klasifikasi ABC Ramanathan

\begin{tabular}{|c|c|c|c|c|c|}
\hline Item & $\mathbf{x i}_{1}$ & $\mathbf{x i}_{2}$ & $\mathbf{x i}_{3}$ & $\begin{array}{c}\text { Skor } \\
\text { (S) }\end{array}$ & Kelas \\
\hline PRE1 & 1,0000 & 0,0226 & 0,0889 & 1,0000 & $\mathrm{~A}$ \\
\hline PRE82 & 0,0001 & 0,0102 & 1,0000 & 1,0000 & A \\
\hline PRE70 & 0,0004 & 1,0000 & 0,4710 & 1,0000 & A \\
\hline PRE59 & 0,0009 & 0,4431 & 0,4710 & 0,7046 & A \\
\hline PRE86 & 0,0000 & 0,0392 & 0,6829 & 0,6999 & A \\
\hline PRE28 & 0,0049 & 0,1359 & 0,4568 & 0,5310 & A \\
\hline PRE19 & 0,0125 & 0,7448 & 0,1093 & 0,5156 & B \\
\hline PRE2 & 0,4338 & 0,0283 & 0,0893 & 0,4940 & B \\
\hline PRE33 & 0,0029 & 0,1225 & 0,4143 & 0,4798 & B \\
\hline PRE7 & 0,0405 & 0,2760 & 0,2480 & 0,4298 & B \\
\hline PRE25 & 0,0067 & 0,3953 & 0,1703 & 0,3855 & B \\
\hline PRE12 & 0,0202 & 0,2846 & 0,2094 & 0,3776 & B \\
\hline PRE15 & 0,0186 & 0,1725 & 0,2582 & 0,3652 & B \\
\hline PRE52 & 0,0011 & 0,0501 & 0,3380 & 0,3638 & B \\
\hline PRE3 & 0,2038 & 0,0231 & 0,1277 & 0,3227 & B \\
\hline PRE68 & 0,0005 & 0,3458 & 0,1350 & 0,3184 & B \\
\hline PRE14 & 0,0192 & 0,4093 & 0,0775 & 0,3118 & B \\
\hline PRE64 & 0,0005 & 0,2650 & 0,1711 & 0,3114 & B \\
\hline PRE36 & 0,0026 & 0,0073 & 0,3061 & 0,3107 & B \\
\hline PRE24 & 0,0072 & 0,3385 & 0,1001 & 0,2858 & B \\
\hline PRE8 & 0,0356 & 0,1205 & 0,1884 & 0,2834 & B \\
\hline PRE45 & 0,0019 & 0,0457 & 0,2477 & 0,2723 & B \\
\hline PRE75 & 0,0003 & 0,2010 & 0,1413 & 0,2475 & $\mathrm{C}$ \\
\hline PRE51 & 0,0012 & 0,2783 & 0,0981 & 0,2465 & $\mathrm{C}$ \\
\hline PRE55 & 0,0010 & 0,0268 & 0,2121 & 0,2261 & $\mathrm{C}$ \\
\hline PRE61 & 0,0008 & 0,4199 & 0,0021 & 0,2259 & $\mathrm{C}$ \\
\hline PRE43 & 0,0020 & 0,3534 & 0,0361 & 0,2254 & $\mathrm{C}$ \\
\hline PRE4 & 0,1690 & 0,0248 & 0,0567 & 0,2217 & $\mathrm{C}$ \\
\hline PRE27 & 0,0062 & 0,0603 & 0,1805 & 0,2171 & $\mathrm{C}$ \\
\hline PRE80 & 0,0002 & 0,3097 & 0,0487 & 0,2131 & $\mathrm{C}$ \\
\hline PRE6 & 0,0850 & 0,1210 & 0,0717 & 0,2120 & $\mathrm{C}$ \\
\hline PRE65 & 0,0005 & 0,0544 & 0,1815 & 0,2098 & $\mathrm{C}$ \\
\hline PRE17 & 0,0177 & 0,2748 & 0,0437 & 0,2054 & $\mathrm{C}$ \\
\hline PRE50 & 0,0012 & 0,2809 & 0,0534 & 0,2034 & $\mathrm{C}$ \\
\hline PRE20 & 0,0110 & 0,1557 & 0,1105 & 0,2025 & $\mathrm{C}$ \\
\hline PRE31 & 0,0039 & 0,1899 & 0,0973 & 0,2011 & $\mathrm{C}$ \\
\hline PRE5 & 0,1382 & 0,0313 & 0,0594 & 0,2001 & $\mathrm{C}$ \\
\hline PRE38 & 0,0026 & 0,1441 & 0,1209 & 0,1991 & $\mathrm{C}$ \\
\hline PRE21 & 0,0097 & 0,3011 & 0,0239 & 0,1925 & $\mathrm{C}$ \\
\hline PRE11 & 0,0284 & 0,2500 & 0,0302 & 0,1883 & $\mathrm{C}$ \\
\hline PRE22 & 0,0095 & 0,0714 & 0,1407 & 0,1865 & $\mathrm{C}$ \\
\hline PRE46 & 0,0018 & 0,0176 & 0,1754 & 0,1855 & $\mathrm{C}$ \\
\hline PRE16 & 0,0186 & 0,0441 & 0,1389 & 0,1783 & $\mathrm{C}$ \\
\hline PRE71 & 0,0004 & 0,0050 & 0,1750 & 0,1771 & $\mathrm{C}$ \\
\hline PRE39 & 0,0026 & 0,0557 & 0,1444 & 0,1755 & $\mathrm{C}$ \\
\hline
\end{tabular}

\begin{tabular}{|c|c|c|c|c|c|}
\hline Item & $\mathbf{x i} \mathbf{1}_{1}$ & $\mathbf{x} \mathbf{i}_{2}$ & $\mathbf{x i} \mathbf{i}_{3}$ & $\begin{array}{c}\text { Skor } \\
\text { (S) }\end{array}$ & Kelas \\
\hline PRE26 & 0,0066 & 0,2265 & 0,0408 & 0,1669 & $\mathrm{C}$ \\
\hline PRE81 & 0,0001 & 0,0749 & 0,1240 & 0,1633 & $\mathrm{C}$ \\
\hline PRE49 & 0,0013 & 0,0801 & 0,1115 & 0,1546 & $\mathrm{C}$ \\
\hline PRE42 & 0,0020 & 0,1703 & 0,0614 & 0,1534 & $\mathrm{C}$ \\
\hline PRE30 & 0,0044 & 0,1990 & 0,0426 & 0,1520 & $\mathrm{C}$ \\
\hline PRE58 & 0,0009 & 0,2643 & 0,0094 & 0,1506 & $\mathrm{C}$ \\
\hline PRE37 & 0,0026 & 0,0659 & 0,1108 & 0,1475 & $\mathrm{C}$ \\
\hline PRE72 & 0,0004 & 0,2415 & 0,0188 & 0,1473 & $\mathrm{C}$ \\
\hline PRE10 & 0,0310 & 0,0836 & 0,0735 & 0,1455 & $\mathrm{C}$ \\
\hline PRE18 & 0,0137 & 0,0193 & 0,1230 & 0,1448 & $\mathrm{C}$ \\
\hline PRE56 & 0,0010 & 0,0347 & 0,1193 & 0,1380 & $\mathrm{C}$ \\
\hline PRE40 & 0,0025 & 0,2228 & 0,0173 & 0,1378 & $\mathrm{C}$ \\
\hline PRE62 & 0,0007 & 0,0223 & 0,1234 & 0,1352 & $\mathrm{C}$ \\
\hline PRE53 & 0,0011 & 0,1551 & 0,0518 & 0,1348 & $\mathrm{C}$ \\
\hline PRE13 & 0,0199 & 0,0863 & 0,0646 & 0,1280 & $\mathrm{C}$ \\
\hline PRE35 & 0,0027 & 0,0574 & 0,0947 & 0,1271 & $\mathrm{C}$ \\
\hline PRE83 & 0,0001 & 0,2297 & 0,0016 & 0,1237 & $\mathrm{C}$ \\
\hline PRE9 & 0,0355 & 0,0428 & 0,0570 & 0,1114 & $\mathrm{C}$ \\
\hline PRE34 & 0,0028 & 0,0181 & 0,0970 & 0,1086 & $\mathrm{C}$ \\
\hline PRE76 & 0,0003 & 0,1107 & 0,0487 & 0,1075 & $\mathrm{C}$ \\
\hline PRE63 & 0,0006 & 0,1069 & 0,0495 & 0,1065 & $\mathrm{C}$ \\
\hline PRE44 & 0,0020 & 0,1569 & 0,0155 & 0,1005 & $\mathrm{C}$ \\
\hline PRE57 & 0,0010 & 0,0353 & 0,0801 & 0,0992 & $\mathrm{C}$ \\
\hline PRE29 & 0,0047 & 0,0706 & 0,0555 & 0,0969 & $\mathrm{C}$ \\
\hline PRE79 & 0,0002 & 0,0282 & 0,0816 & 0,0964 & $\mathrm{C}$ \\
\hline PRE66 & 0,0005 & 0,0962 & 0,0351 & 0,0864 & $\mathrm{C}$ \\
\hline PRE85 & 0,0000 & 0,0652 & 0,0487 & 0,0831 & $\mathrm{C}$ \\
\hline PRE73 & 0,0003 & 0,0775 & 0,0361 & 0,0774 & $\mathrm{C}$ \\
\hline PRE67 & 0,0005 & 0,0939 & 0,0262 & 0,0764 & $\mathrm{C}$ \\
\hline PRE23 & 0,0091 & 0,0911 & 0,0173 & 0,0737 & $\mathrm{C}$ \\
\hline PRE69 & 0,0004 & 0,0614 & 0,0392 & 0,0720 & $\mathrm{C}$ \\
\hline PRE74 & 0,0003 & 0,1249 & 0,0031 & 0,0697 & $\mathrm{C}$ \\
\hline PRE41 & 0,0021 & 0,0000 & 0,0672 & 0,0687 & $\mathrm{C}$ \\
\hline PRE60 & 0,0008 & 0,1273 & 0,0000 & 0,0683 & $\mathrm{C}$ \\
\hline PRE84 & 0,0000 & 0,0108 & 0,0597 & 0,0651 & $\mathrm{C}$ \\
\hline PRE47 & 0,0018 & 0,0350 & 0,0406 & 0,0606 & $\mathrm{C}$ \\
\hline PRE54 & 0,0010 & 0,0733 & 0,0116 & 0,0514 & $\mathrm{C}$ \\
\hline PRE78 & 0,0002 & 0,0482 & 0,0204 & 0,0461 & $\mathrm{C}$ \\
\hline PRE32 & 0,0034 & 0,0385 & 0,0113 & 0,0348 & $\mathrm{C}$ \\
\hline PRE48 & 0,0017 & 0,0340 & 0,0026 & 0,0222 & $\mathrm{C}$ \\
\hline PRE77 & 0,0002 & 0,0041 & 0,0157 & 0,0180 & $\mathrm{C}$ \\
\hline
\end{tabular}

\subsection{Model Klasifikasi ABC Ng}

Model ini menyajikan cara yang lebih sederhana dalam menyusun klasifikasi ABC multi kriteria (MCIC). Nilai transformasi kriteria $\mathrm{j}$ untuk item i $\left(x_{i j}\right)$ digunakan untuk 
mencari nilai partial average menggunakan persamaan $\frac{1}{j} \sum_{k=1}^{k=j} x_{i j}$

Tabel 3. Hasil perhitungan Model ABC Ng

\begin{tabular}{|c|c|c|c|c|c|}
\hline \multirow{2}{*}{ Item } & \multicolumn{3}{|c|}{ Partial Average } & \multirow{2}{*}{$\begin{array}{c}\text { Skor } \\
\text { (S) } \\
\end{array}$} & \multirow{2}{*}{ Kelas } \\
\hline & 1 & 2 & 3 & & \\
\hline PRE1 & 1,0000 & 0,5113 & 0,3705 & 1,0000 & A \\
\hline PRE70 & 0,0004 & 0,5002 & 0,4905 & 0,5002 & A \\
\hline PRE2 & 0,4338 & 0,2310 & 0,1838 & 0,4338 & A \\
\hline PRE19 & 0,0125 & 0,3786 & 0,2888 & 0,3786 & A \\
\hline PRE82 & 0,0001 & 0,0052 & 0,3368 & 0,3368 & A \\
\hline PRE59 & 0,0009 & 0,2220 & $\mathbf{0 , 3 0 5 0}$ & 0,3050 & A \\
\hline PRE86 & 0,0000 & 0,0196 & 0,2407 & 0,2407 & $\mathrm{~B}$ \\
\hline PRE14 & 0,0192 & 0,2143 & 0,1687 & 0,2143 & $\mathrm{~B}$ \\
\hline PRE61 & 0,0008 & 0,2104 & 0,1409 & 0,2104 & $\mathrm{~B}$ \\
\hline PRE3 & 0,2038 & 0,1134 & 0,1182 & 0,2038 & $\mathrm{~B}$ \\
\hline PRE25 & 0,0067 & 0,2010 & 0,1908 & 0,2010 & B \\
\hline PRE28 & 0,0049 & 0,0704 & 0,1992 & 0,1992 & $\mathrm{~B}$ \\
\hline PRE7 & 0,0405 & 0,1583 & 0,1882 & 0,1882 & B \\
\hline PRE33 & 0,0029 & 0,0627 & 0,1799 & 0,1799 & B \\
\hline PRE43 & 0,0020 & $\mathbf{0 , 1 7 7 7}$ & 0,1305 & 0,1777 & B \\
\hline PRE68 & 0,0005 & $\mathbf{0 , 1 7 3 1}$ & 0,1604 & 0,1731 & B \\
\hline PRE24 & 0,0072 & 0,1728 & 0,1486 & 0,1728 & B \\
\hline PRE12 & 0,0202 & 0,1524 & 0,1714 & 0,1714 & B \\
\hline PRE4 & 0,1690 & 0,0969 & 0,0835 & 0,1690 & B \\
\hline PRE21 & 0,0097 & 0,1554 & 0,1116 & 0,1554 & B \\
\hline PRE80 & 0,0002 & 0,1549 & 0,1195 & 0,1549 & B \\
\hline PRE15 & 0,0186 & 0,0956 & 0,1498 & 0,1498 & B \\
\hline PRE17 & 0,0177 & 0,1462 & 0,1121 & 0,1462 & $\mathrm{C}$ \\
\hline PRE64 & 0,0005 & 0,1328 & 0,1455 & 0,1455 & $\mathrm{C}$ \\
\hline PRE50 & 0,0012 & 0,1411 & 0,1118 & 0,1411 & $\mathrm{C}$ \\
\hline PRE51 & 0,0012 & 0,1398 & 0,1259 & 0,1398 & $\mathrm{C}$ \\
\hline PRE11 & 0,0284 & 0,1392 & 0,1028 & 0,1392 & $\mathrm{C}$ \\
\hline PRE5 & 0,1382 & 0,0848 & 0,0763 & 0,1382 & $\mathrm{C}$ \\
\hline PRE58 & 0,0009 & 0,1326 & 0,0916 & 0,1326 & $\mathrm{C}$ \\
\hline PRE52 & 0,0011 & 0,0256 & 0,1297 & 0,1297 & $\mathrm{C}$ \\
\hline PRE72 & 0,0004 & 0,1209 & 0,0869 & 0,1209 & $\mathrm{C}$ \\
\hline PRE26 & 0,0066 & 0,1166 & 0,0913 & 0,1166 & $\mathrm{C}$ \\
\hline PRE83 & 0,0001 & 0,1149 & 0,0771 & 0,1149 & $\mathrm{C}$ \\
\hline PRE8 & 0,0356 & 0,0781 & 0,1148 & 0,1148 & $\mathrm{C}$ \\
\hline PRE75 & 0,0003 & 0,1006 & 0,1142 & 0,1142 & $\mathrm{C}$ \\
\hline PRE40 & 0,0025 & 0,1126 & 0,0808 & 0,1126 & $\mathrm{C}$ \\
\hline PRE36 & 0,0026 & 0,0050 & 0,1053 & 0,1053 & $\mathrm{C}$ \\
\hline PRE6 & 0,0850 & 0,1030 & 0,0925 & 0,1030 & $\mathrm{C}$ \\
\hline PRE30 & 0,0044 & 0,1017 & 0,0820 & 0,1017 & $\mathrm{C}$ \\
\hline PRE45 & 0,0019 & 0,0238 & 0,0984 & 0,0984 & $\mathrm{C}$ \\
\hline PRE31 & 0,0039 & 0,0969 & 0,0970 & 0,0970 & $\mathrm{C}$ \\
\hline PRE20 & 0,0110 & 0,0833 & 0,0924 & 0,0924 & $\mathrm{C}$ \\
\hline PRE38 & 0,0026 & 0,0733 & 0,0892 & 0,0892 & $\mathrm{C}$ \\
\hline PRE42 & 0,0020 & 0,0862 & 0,0779 & 0,0862 & $\mathrm{C}$ \\
\hline PRE27 & 0,0062 & 0,0333 & $\mathbf{0 , 0 8 2 3}$ & 0,0823 & $\mathrm{C}$ \\
\hline
\end{tabular}

\begin{tabular}{|c|c|c|c|c|c|}
\hline \multirow{2}{*}{ Item } & \multicolumn{3}{|c|}{ Partial Average } & \multirow{2}{*}{$\begin{array}{c}\text { Skor } \\
(\mathbf{S})\end{array}$} & \multirow{2}{*}{ Kelas } \\
\hline & 1 & 2 & 3 & & \\
\hline PRE55 & 0,0010 & 0,0139 & 0,0800 & 0,0800 & $\mathrm{C}$ \\
\hline PRE44 & 0,0020 & 0,0794 & 0,0581 & 0,0794 & $\mathrm{C}$ \\
\hline PRE65 & 0,0005 & 0,0274 & 0,0788 & 0,0788 & $\mathrm{C}$ \\
\hline PRE53 & 0,0011 & 0,0781 & 0,0693 & 0,0781 & $\mathrm{C}$ \\
\hline PRE22 & 0,0095 & 0,0405 & 0,0739 & 0,0739 & $\mathrm{C}$ \\
\hline PRE39 & 0,0026 & 0,0291 & 0,0675 & 0,0675 & $\mathrm{C}$ \\
\hline PRE16 & 0,0186 & 0,0313 & 0,0672 & 0,0672 & $\mathrm{C}$ \\
\hline PRE81 & 0,0001 & 0,0375 & 0,0664 & 0,0664 & $\mathrm{C}$ \\
\hline PRE46 & 0,0018 & 0,0097 & 0,0650 & 0,0650 & $\mathrm{C}$ \\
\hline PRE49 & 0,0013 & 0,0407 & 0,0643 & 0,0643 & $\mathrm{C}$ \\
\hline PRE60 & 0,0008 & 0,0640 & 0,0427 & 0,0640 & $\mathrm{C}$ \\
\hline PRE10 & 0,0310 & 0,0573 & 0,0627 & 0,0627 & $\mathrm{C}$ \\
\hline PRE74 & 0,0003 & 0,0626 & 0,0428 & 0,0626 & $\mathrm{C}$ \\
\hline PRE71 & 0,0004 & 0,0027 & 0,0601 & 0,0601 & $\mathrm{C}$ \\
\hline PRE37 & 0,0026 & 0,0343 & 0,0598 & 0,0598 & $\mathrm{C}$ \\
\hline PRE13 & 0,0199 & 0,0531 & 0,0569 & 0,0569 & $\mathrm{C}$ \\
\hline PRE76 & 0,0003 & 0,0555 & 0,0532 & 0,0555 & $\mathrm{C}$ \\
\hline PRE63 & 0,0006 & $\mathbf{0 , 0 5 3 7}$ & 0,0523 & 0,0537 & $\mathrm{C}$ \\
\hline PRE18 & 0,0137 & 0,0165 & 0,0520 & 0,0520 & $\mathrm{C}$ \\
\hline PRE56 & 0,0010 & 0,0179 & 0,0517 & 0,0517 & $\mathrm{C}$ \\
\hline PRE35 & 0,0027 & 0,0301 & 0,0516 & 0,0516 & $\mathrm{C}$ \\
\hline PRE23 & 0,0091 & $\mathbf{0 , 0 5 0 1}$ & 0,0391 & 0,0501 & $\mathrm{C}$ \\
\hline PRE62 & 0,0007 & 0,0115 & 0,0488 & 0,0488 & $\mathrm{C}$ \\
\hline PRE66 & 0,0005 & 0,0484 & 0,0439 & 0,0484 & $\mathrm{C}$ \\
\hline PRE67 & 0,0005 & 0,0472 & 0,0402 & 0,0472 & $\mathrm{C}$ \\
\hline PRE9 & 0,0355 & 0,0392 & 0,0451 & 0,0451 & $\mathrm{C}$ \\
\hline PRE29 & 0,0047 & 0,0376 & 0,0436 & 0,0436 & $\mathrm{C}$ \\
\hline PRE34 & 0,0028 & 0,0104 & 0,0393 & 0,0393 & $\mathrm{C}$ \\
\hline PRE73 & 0,0003 & $\mathbf{0 , 0 3 8 9}$ & 0,0380 & 0,0389 & $\mathrm{C}$ \\
\hline PRE57 & 0,0010 & 0,0181 & $\mathbf{0 , 0 3 8 8}$ & 0,0388 & $\mathrm{C}$ \\
\hline PRE85 & 0,0000 & 0,0326 & $\mathbf{0 , 0 3 8 0}$ & 0,0380 & $\mathrm{C}$ \\
\hline PRE54 & 0,0010 & 0,0372 & 0,0286 & 0,0372 & $\mathrm{C}$ \\
\hline PRE79 & 0,0002 & 0,0142 & 0,0367 & 0,0367 & $\mathrm{C}$ \\
\hline PRE69 & 0,0004 & 0,0309 & $\mathbf{0 , 0 3 3 7}$ & 0,0337 & $\mathrm{C}$ \\
\hline PRE47 & 0,0018 & 0,0184 & 0,0258 & 0,0258 & $\mathrm{C}$ \\
\hline PRE78 & 0,0002 & 0,0242 & 0,0230 & 0,0242 & $\mathrm{C}$ \\
\hline PRE84 & 0,0000 & 0,0054 & $\mathbf{0 , 0 2 3 5}$ & 0,0235 & $\mathrm{C}$ \\
\hline PRE41 & 0,0021 & 0,0010 & $\mathbf{0 , 0 2 3 1}$ & 0,0231 & $\mathrm{C}$ \\
\hline PRE32 & 0,0034 & 0,0210 & 0,0177 & 0,0210 & $\mathrm{C}$ \\
\hline PRE48 & 0,0017 & 0,0179 & 0,0128 & 0,0179 & $\mathrm{C}$ \\
\hline PRE77 & 0,0002 & 0,0022 & 0,0067 & 0,0067 & $\mathrm{C}$ \\
\hline
\end{tabular}

Tabel 3 menunjukan hasil dari perhitungan partial average disusun dalam spreadsheet masing-masing item. Pada setiap item i dipilih nilai partial average tertinggi sebagai skor item tersebut. Proses dilanjutkan sampai seluruh item i telah ditentukan nilai skornya. Skor tersebut kemudian disusun 
dengan urutan skor terbesar menuju ke skor terkecil. Klasifikasi ABC dapat ditentukan sesuai dengan urutan skor descending.

Misal untuk item PRE70, hasil perhitungan partial average menunjukan bahwa, nilai maksimal partial average item PRE70 adalah partial average nomor 2. Artinya bahwa item tersebut diklasifikasikan pada barang kelas A dengan urutan skor tertinggi kedua dikarenakan skor partial average untu kriteria biaya per unit paling tinggi. item PRE70 dianggap penting karena memiliki nilai per unit yang cukup tinggi dibandingkan dengan kriteria yang lain (Lead Time dan Annual Value). Contoh lain misalnya untuk item PRE82 sebagai kelas A pada model $\mathrm{Ng}$ karena nilai partial average untuk kriteria Lead Time lebih tinggi dibandingkan dengan kriteria annual value dan biaya per unit.

\subsection{Perbandingan Model Klasifikasi}

Pada klasifikasi model ABC tradisional, item PRE1, PRE2, PRE3, PRE4, PRE 5 dan PRE 6 dikelompokan pada kelas $S$ dengan mempertingbangkan kontribusi total annual value untuk keenam kelompok tersebut memiliki porse sebesar $81,5 \%$. Sementara, dari hasil klasifikasi dengan 3 kriteria yang dipertimbangkan, baik model Ramanathan (R) dan $\mathrm{Ng}$ menghasilkan klasifikasi yang sama untuk item PRE1 sebagai kelas A. Pada item PRE2, model Ng dan tradisional memberikan klasifikasi kelas A, sedangkan dalam model Ramanathan, item tersebut ditetapkan sebagai kelas B. Lebih jelas, perbandingan hasil klasifikasi tradisional (single criteria), model Ramanathan (MCIC) dan Ng (MCIC) disajikan pada Tabel 4.

Model Ramanathan menggunakan bobot linear kriteria dimana agregrat performansi dari masing - masing item dikalkulasikan ke dalam single score item yang bersangkutan. Model ini memiliki kelemahan diskriminasi power pada kriteria masing-masing item. Optimisasi pada model Ramanathan memberikan hasil bobot masing - masing kriteria untuk seluruh item yang menghasilkan skor total optimum antar item adalah:

a) Annual value dengan bobot 0,8996

b) Unit cost dengan bobot 0,5313

c) Lead time dengan bobot 0,9945

Sama dengan model Ramanathan, Model $\mathrm{Ng}$ juga menggunakan bobot linear kriteria dan meminimasi subjektivitas dalam menentukan skor. Skor item yang diperoleh model $\mathrm{Ng}$ merupakan bobot item yang independen yang berupa partial average kriteria.

Hasil ini memberikan gambaran bahwa dengan menggunakan multi kriteria, barang dengan annual value tinggi belum tentu dikategorikan kelas A berdasarkan pertimbangan dari kriteria lain yang memiliki skor ebih tinggi. Item PRE70 dengan nilai annual value kecil dikategorikan sebagai kelas $\mathrm{C}$ pada model Tradisional, namun model Ramanathan dan $\mathrm{Ng}$ sebagai kelas A. PRE70 ditetapkan sebagai kelas A pada model Ramanathan dan $\mathrm{Ng}$ karena memiliki cost per unit dan Lead Time yang besar.

Dengan mempertimbangkan berbagai model klasifikasi yang telah dilakukan, kebijakan inventori yang dilakukan adalah menggunakan kebijakan berdasarkan kelas yang lebih tinggi untuk masing - masing item. Kebijakan day-by-day inventory diterapkan pada item PRE 86 dengan mempertimbangkan hasil kelas A yang didapat pada model Ramanthan, begitu pula untuk item PRE 43 diperlukan kebijakan periodic review berdasarkan hasil klasifikasi model $\mathrm{Ng}$ sebagai kelas B. Usulan kebijakan untuk seluruh item dapat dilihat pada Tabel.4.

Tabel 4. Model Tradisional, $\mathrm{R}$ dan $\mathrm{Ng}$

\begin{tabular}{|c|c|c|c|c|c|c|c|}
\hline Item & $\begin{array}{c}\text { Annual } \\
\text { Value } \\
\text { (Rp. Ribu) }\end{array}$ & $\begin{array}{l}\text { Cost/ unit } \\
\text { (Rp) }\end{array}$ & LT & $\mathrm{Ng}$ & $\mathrm{R}$ & Trad. & Usulan \\
\hline PRE1 & 18.043 .226 & 253.640 & 61 & A & A & A & $\mathrm{A}$ \\
\hline PRE70 & 8.224 & 5.253 .773 & 304 & A & A & $\mathrm{C}$ & A \\
\hline PRE2 & 7.827 .558 & 282.702 & 61 & A & B & A & A \\
\hline PRE19 & 226.531 & 3.948 .035 & 74 & A & B & B & A \\
\hline PRE82 & 3.425 & 190.301 & 641 & A & A & $\mathrm{C}$ & A \\
\hline
\end{tabular}




\begin{tabular}{|c|c|c|c|c|c|c|c|}
\hline Item & $\begin{array}{c}\text { Annual } \\
\text { Value } \\
\text { (Rp. Ribu) }\end{array}$ & $\begin{array}{l}\text { Cost/ unit } \\
\text { (Rp) }\end{array}$ & LT & $\mathrm{Ng}$ & $\mathrm{R}$ & Trad. & Usulan \\
\hline PRE59 & 18.072 & 2.404 .847 & 304 & A & A & C & A \\
\hline PRE86 & 1.001 & 338.748 & 439 & B & A & $\mathrm{C}$ & A \\
\hline PRE14 & 347.804 & 2.232 .115 & 53 & B & B & B & B \\
\hline PRE61 & 15.188 & 2.286 .440 & 5 & B & $\mathrm{C}$ & $\mathrm{C}$ & B \\
\hline PRE3 & 3.678 .559 & 256.135 & 85 & B & B & A & A \\
\hline PRE25 & 122.460 & 2.160 .256 & 113 & B & B & $\mathrm{C}$ & B \\
\hline PRE28 & 89.910 & 833.500 & 295 & B & A & $\mathrm{C}$ & A \\
\hline PRE7 & 732.298 & 1.550 .166 & 162 & B & B & $\mathrm{B}$ & B \\
\hline PRE33 & 53.946 & 765.028 & 268 & B & B & $\mathrm{C}$ & B \\
\hline PRE43 & 36.861 & 1.945 .891 & 27 & B & $\mathrm{C}$ & $\mathrm{C}$ & B \\
\hline PRE68 & 9.465 & 1.907 .140 & 90 & B & B & $\mathrm{C}$ & B \\
\hline PRE24 & 130.356 & 1.869 .655 & 68 & B & B & $\mathrm{C}$ & B \\
\hline PRE12 & 364.771 & 1.594 .054 & 137 & B & B & $\mathrm{B}$ & B \\
\hline PRE4 & 3.050 .815 & 265.065 & 40 & B & $\mathrm{C}$ & A & A \\
\hline PRE21 & 176.645 & 1.678 .308 & 19 & B & $\mathrm{C}$ & B & B \\
\hline PRE80 & 4.106 & 1.722 .399 & 35 & B & $\mathrm{C}$ & $\mathrm{C}$ & B \\
\hline PRE15 & 337.425 & 1.020 .430 & 168 & B & B & B & B \\
\hline PRE17 & 321.024 & 1.543 .708 & 32 & $\mathrm{C}$ & $\mathrm{C}$ & B & B \\
\hline PRE64 & 10.470 & 1.493 .787 & 113 & $\mathrm{C}$ & B & $\mathrm{C}$ & B \\
\hline PRE50 & 23.076 & 1.575 .163 & 38 & $\mathrm{C}$ & $\mathrm{C}$ & $\mathrm{C}$ & $\mathrm{C}$ \\
\hline PRE51 & 23.044 & 1.561 .762 & 67 & $\mathrm{C}$ & $\mathrm{C}$ & $\mathrm{C}$ & $\mathrm{C}$ \\
\hline PRE11 & 512.616 & 1.417 .035 & 23 & $\mathrm{C}$ & $\mathrm{C}$ & B & B \\
\hline PRE5 & 2.495 .040 & 298.305 & 42 & $\mathrm{C}$ & $\mathrm{C}$ & A & A \\
\hline PRE58 & 18.095 & 1.490 .280 & 10 & $\mathrm{C}$ & $\mathrm{C}$ & $\mathrm{C}$ & $\mathrm{C}$ \\
\hline PRE52 & 21.560 & 394.172 & 219 & $\mathrm{C}$ & B & $\mathrm{C}$ & B \\
\hline PRE72 & 7.402 & 1.373 .402 & 16 & $\mathrm{C}$ & $\mathrm{C}$ & $\mathrm{C}$ & $\mathrm{C}$ \\
\hline PRE26 & 120.528 & 1.296 .715 & 30 & $\mathrm{C}$ & $\mathrm{C}$ & $\mathrm{C}$ & $\mathrm{C}$ \\
\hline PRE83 & 2.749 & 1.313 .122 & 5 & $\mathrm{C}$ & $\mathrm{C}$ & $\mathrm{C}$ & $\mathrm{C}$ \\
\hline PRE8 & 643.388 & 754.604 & 124 & $\mathrm{C}$ & B & B & B \\
\hline PRE75 & 5.804 & 1.166 .127 & 94 & $\mathrm{C}$ & $\mathrm{C}$ & $\mathrm{C}$ & $\mathrm{C}$ \\
\hline PRE40 & 45.774 & 1.277 .667 & 15 & $\mathrm{C}$ & $\mathrm{C}$ & $\mathrm{C}$ & $\mathrm{C}$ \\
\hline PRE36 & 48.620 & 175.404 & 199 & $\mathrm{C}$ & B & $\mathrm{C}$ & B \\
\hline PRE6 & 1.534 .092 & 756.956 & 50 & $\mathrm{C}$ & $\mathrm{C}$ & A & A \\
\hline PRE30 & 79.610 & 1.156 .056 & 31 & $\mathrm{C}$ & $\mathrm{C}$ & $\mathrm{C}$ & $\mathrm{C}$ \\
\hline PRE45 & 34.776 & 371.723 & 162 & $\mathrm{C}$ & B & $\mathrm{C}$ & B \\
\hline PRE31 & 71.431 & 1.109 .380 & 66 & $\mathrm{C}$ & $\mathrm{C}$ & $\mathrm{C}$ & $\mathrm{C}$ \\
\hline PRE20 & 199.586 & 934.562 & 74 & $\mathrm{C}$ & $\mathrm{C}$ & B & B \\
\hline PRE38 & 47.410 & 875.083 & 81 & $\mathrm{C}$ & $\mathrm{C}$ & $\mathrm{C}$ & $\mathrm{C}$ \\
\hline PRE42 & 37.378 & 1.009 .274 & 43 & $\mathrm{C}$ & $\mathrm{C}$ & $\mathrm{C}$ & $\mathrm{C}$ \\
\hline PRE27 & 113.399 & 446.805 & 119 & $\mathrm{C}$ & $\mathrm{C}$ & $\mathrm{C}$ & $\mathrm{C}$ \\
\hline PRE55 & 19.845 & 275.363 & 139 & $\mathrm{C}$ & $\mathrm{C}$ & $\mathrm{C}$ & $\mathrm{C}$ \\
\hline PRE44 & 36.840 & 940.727 & 14 & $\mathrm{C}$ & $\mathrm{C}$ & $\mathrm{C}$ & $\mathrm{C}$ \\
\hline PRE65 & 10.032 & 416.274 & 120 & $\mathrm{C}$ & $\mathrm{C}$ & $\mathrm{C}$ & $\mathrm{C}$ \\
\hline PRE53 & 20.075 & 931.326 & 37 & $\mathrm{C}$ & $\mathrm{C}$ & $\mathrm{C}$ & $\mathrm{C}$ \\
\hline PRE22 & 172.794 & 503.609 & 94 & $\mathrm{C}$ & $\mathrm{C}$ & B & B \\
\hline PRE39 & 47.058 & 422.880 & 96 & $\mathrm{C}$ & $\mathrm{C}$ & $\mathrm{C}$ & $\mathrm{C}$ \\
\hline PRE16 & 336.224 & 363.709 & 93 & $\mathrm{C}$ & $\mathrm{C}$ & B & B \\
\hline PRE81 & 3.628 & 521.517 & 83 & $\mathrm{C}$ & $\mathrm{C}$ & $\mathrm{C}$ & $\mathrm{C}$ \\
\hline PRE46 & 34.056 & 228.393 & 116 & $\mathrm{C}$ & $\mathrm{C}$ & $\mathrm{C}$ & $\mathrm{C}$ \\
\hline PRE49 & 23.976 & 548.046 & 75 & $\mathrm{C}$ & $\mathrm{C}$ & $\mathrm{C}$ & $\mathrm{C}$ \\
\hline PRE60 & 15.576 & 789.224 & 4 & $\mathrm{C}$ & $\mathrm{C}$ & $\mathrm{C}$ & C \\
\hline PRE10 & 561.117 & 565.552 & 51 & $\mathrm{C}$ & $\mathrm{C}$ & B & B \\
\hline PRE74 & 6.225 & 777.050 & 6 & $\mathrm{C}$ & $\mathrm{C}$ & $\mathrm{C}$ & C \\
\hline PRE71 & 8.060 & 163.956 & 115 & $\mathrm{C}$ & $\mathrm{C}$ & C & $\mathrm{C}$ \\
\hline PRE37 & 47.736 & 475.427 & 75 & $\mathrm{C}$ & $\mathrm{C}$ & $\mathrm{C}$ & $\mathrm{C}$ \\
\hline PRE13 & 359.640 & 579.496 & 45 & $\mathrm{C}$ & $\mathrm{C}$ & B & B \\
\hline PRE76 & 5.782 & 704.554 & 35 & $\mathrm{C}$ & $\mathrm{C}$ & $\mathrm{C}$ & C \\
\hline PRE63 & 11.680 & 684.739 & 36 & $\mathrm{C}$ & $\mathrm{C}$ & $\mathrm{C}$ & $\mathrm{C}$ \\
\hline PRE18 & 247.690 & 236.907 & 82 & $\mathrm{C}$ & $\mathrm{C}$ & B & B \\
\hline
\end{tabular}

\begin{tabular}{rrrrrrrr}
\hline \hline Item & $\begin{array}{c}\text { Annual } \\
\text { Value } \\
\text { (Rp. Ribu) }\end{array}$ & $\begin{array}{c}\text { Cost/ unit } \\
\text { (Rp) }\end{array}$ & LT & Ng & R & Trad. & Usulan \\
\hline \hline PRE56 & 19.000 & 315.875 & 80 & $\mathrm{C}$ & $\mathrm{C}$ & $\mathrm{C}$ & $\mathrm{C}$ \\
PRE35 & 49.980 & 431.834 & 64 & $\mathrm{C}$ & $\mathrm{C}$ & $\mathrm{C}$ & $\mathrm{C}$ \\
PRE23 & 164.754 & 604.155 & 15 & $\mathrm{C}$ & $\mathrm{C}$ & $\mathrm{C}$ & $\mathrm{C}$ \\
PRE62 & 13.857 & 252.089 & 83 & $\mathrm{C}$ & $\mathrm{C}$ & $\mathrm{C}$ & $\mathrm{C}$ \\
PRE66 & 9.568 & 630.429 & 26 & $\mathrm{C}$ & $\mathrm{C}$ & $\mathrm{C}$ & $\mathrm{C}$ \\
PRE67 & 9.514 & 618.667 & 21 & $\mathrm{C}$ & $\mathrm{C}$ & $\mathrm{C}$ & $\mathrm{C}$ \\
PRE9 & 641.232 & 357.268 & 40 & $\mathrm{C}$ & $\mathrm{C}$ & $\mathrm{B}$ & $\mathrm{B}$ \\
PRE29 & 85.746 & 499.206 & 39 & $\mathrm{C}$ & $\mathrm{C}$ & $\mathrm{C}$ & $\mathrm{C}$ \\
PRE34 & 51.156 & 230.595 & 66 & $\mathrm{C}$ & $\mathrm{C}$ & $\mathrm{C}$ & $\mathrm{C}$ \\
PRE73 & 6.846 & 534.434 & 27 & $\mathrm{C}$ & $\mathrm{C}$ & $\mathrm{C}$ & $\mathrm{C}$ \\
PRE57 & 18.390 & 318.518 & 55 & $\mathrm{C}$ & $\mathrm{C}$ & $\mathrm{C}$ & $\mathrm{C}$ \\
PRE85 & 1.223 & 471.703 & 35 & $\mathrm{C}$ & $\mathrm{C}$ & $\mathrm{C}$ & $\mathrm{C}$ \\
PRE54 & 19.910 & 513.003 & 11 & $\mathrm{C}$ & $\mathrm{C}$ & $\mathrm{C}$ & $\mathrm{C}$ \\
PRE79 & 4.896 & 282.556 & 56 & $\mathrm{C}$ & $\mathrm{C}$ & $\mathrm{C}$ & $\mathrm{C}$ \\
PRE69 & 8.502 & 452.073 & 29 & $\mathrm{C}$ & $\mathrm{C}$ & $\mathrm{C}$ & $\mathrm{C}$ \\
PRE47 & 33.475 & 317.344 & 30 & $\mathrm{C}$ & $\mathrm{C}$ & $\mathrm{C}$ & $\mathrm{C}$ \\
PRE78 & 5.040 & 384.852 & 17 & $\mathrm{C}$ & $\mathrm{C}$ & $\mathrm{C}$ & $\mathrm{C}$ \\
PRE84 & 1.503 & 193.361 & 42 & $\mathrm{C}$ & $\mathrm{C}$ & $\mathrm{C}$ & $\mathrm{C}$ \\
PRE41 & 38.544 & 138.123 & 47 & $\mathrm{C}$ & $\mathrm{C}$ & $\mathrm{C}$ & $\mathrm{C}$ \\
PRE32 & 62.130 & 335.250 & 11 & $\mathrm{C}$ & $\mathrm{C}$ & $\mathrm{C}$ & $\mathrm{C}$ \\
PRE48 & 32.373 & 312.232 & 6 & $\mathrm{C}$ & $\mathrm{C}$ & $\mathrm{C}$ & $\mathrm{C}$ \\
PRE77 & 5.080 & 159.112 & 14 & $\mathrm{C}$ & $\mathrm{C}$ & $\mathrm{C}$ & $\mathrm{C}$ \\
\hline \hline
\end{tabular}

Jika dilihat dari porsi penyerapan dana (annual value) terhadap persediaan barang, kelas A memiliki porsi $81 \%$ pada model tradisional, $40 \%$ pada model Ramanathan dan 58\% pada model $\mathrm{Ng}$. selengkapnya, porsi penggunaan modal masing - masing model dapat dilihat pada tabel $\mathbf{5}$ di bawah. Penyerapan dana dalam hal ini adalah biaya yang dikeluarkan untuk mendapatkan produk sampai berada di gudang perusahaan.

Tabel 5. Porsi peyerapan modal

\begin{tabular}{lccc}
\hline \hline \multirow{2}{*}{ Model } & \multicolumn{3}{c}{ \% annual value } \\
\cline { 2 - 4 } & A & B & C \\
\hline \hline Tradisional & 81 & 14 & 5 \\
Ramanathan & 40 & 33 & 27 \\
$\mathrm{Ng}$ & 58 & 20 & 22 \\
Usulan & 82 & 14 & 4 \\
\hline \hline
\end{tabular}

Penerapan kebijakan ini dilakukan dengan mengelola kelas A berada pada tingkat persediaan 14\%, kelas B 30\% dan kelas C sebesar $56 \%$ dari total seluruh item persediaan. Dengan penerapan kebijakan ini, akan memberikan dampak terhadap porsi penyerapan modal kelas A sebesar $82 \%$, kelas B 14\% dan kelas C sebesar 4\%. 


\section{KESIMPULAN}

Dalam mengelola persediaan, beberapa kebijakan pengendalian persediaan dapat dipertimbangkan antara lain day by day untuk kelas $\mathrm{A}$, periodic review untuk kelas $\mathrm{B}$ dan infrequent review pada kelas C [10]. Kelas A dengan kebijakan day by day atau continuous review bertujuan mengelola barang dengan porsi penyerapan modal terbesar dan memiliki potensi stock-out besar dengan pemantauan persediaan setiap hari. Penerapan kebijakan pada penelitian ini dilakukan dengan mengelola kelas A berada pada tingkat persediaan $14 \%$, kelas B 30\% dan kelas C sebesar $56 \%$ dari total seluruh item persediaan.

Penentuan model klasifikasi dengan MCIC dapat dijadikan pertimbangan bahwa dalam menetapkan kelas produk, kriteria kepentingan produk tidak hanya berdasarkan pada annual value. Model $A B C$ dapat memberikan gambaran tentang kepentingan suatu produk dilihat dari berbagai faktor seperti annual value, lead time dan cost per unit. Pada penelitian selanjutnya, dapat dikembangkan dengan mempertimbangkan stochastic demand, stochastic lead time, perishable dan obsolescence produk yang dikelola.

\section{DAFTAR PUSTAKA}

[1] F. Lolli, A. Ishizaka, and R. Gamberini, "New AHP-based approaches for multi-criteria inventory classification," International Journal of Production Economics, vol. 156, pp. 62-74, 2014.

[2] Q. Iqbal, D. Malzahn, and L. E. Whitman, "Selecting a Multicriteria Inventory Classification Model to Improve Customer Order Fill Rate," Advances in Decision Sciences, vol. 2017, p. 11, 2017.

[3] C.-W. Chu, G.-S. Liang, and C.-T. Liao, "Controlling inventory by combining $\mathrm{ABC}$ analysis and fuzzy classification," Computers \& Industrial Engineering, vol. 55, pp. 841-851, 2008.

[4] J. Rezaei and S. Dowlatshahi, "A rulebased multi-criteria approach to inventory classification," International Journal of Production Research - INT J PROD RES, vol. 48, pp. 7107-7126, 2010.

[5] G. Keskin and C. Ozkan, "Multiple criteria $\mathrm{ABC}$ analysis with FCM clustering," Journal of Industrial Engineering, vol. 2013,.

[6] R. Ramanathan, "ABC inventory classification with multiple-criteria using weighted linear optimization," Computers \& Operations Research, vol. 33, pp. 695-700, 2006.

[7] W. L. Ng, "A simple classifier for multiple criteria ABC analysis," European Journal of Operational Research, vol. 177, pp. 344-353, 2007.

[8] M. Millstein, L. Yang, and H. Li, "Optimizing ABC Inventory Grouping Decisions," International Journal of Production Economics, vol. 148, 2013.

[9] S. M. Hatefi, S. A. Torabi, and P. Bagheri, "Multi-criteria ABC inventory classification with mixed quantitative and qualitative criteria," International Journal of Production Research, vol. 52, pp. 776-786, 2014.

[10] B. Pandya ${ }^{1}$ and H. Thakkar, "A Review on Inventory Management Control Techniques: ABC-XYZ Analysis," REST Journal on Emerging trends in Modelling and Manufacturing, vol. 2, p. 15, 2016. 
[11] A. Serawati, S. Wahyudi, and S. D. Surjanto, "Klasifikasi ABC denganMulti-kriteria Menggunakan Ng-Model untuk Pengendalian Persediaan," Jurnal Sains dan Seni ITS, vol. 3, pp. A46-A52, 2014.

[12] E. Kıyak, O. Timuş, and M. Karayel, "Inventory classification with ABC analysis," Journal of Naval Sciences and Engineering, vol. 11, pp. 11-24, 2015.

[13] A. Bhattacharya, B. Sarkar, and S. K. Mukherjee, "Distance-based consensus method for ABC analysis," International Journal of Production Research, vol. 45, pp. 3405-3420, 2007.

[14] M. Ben Jeddou, "Multi-Criteria ABC Inventory Classification- A Case of Vehicles Spare Parts Items," Journal of Advanced Management Science, pp. 181-185, 2014.

[15] B. E. Flores, D. L. Olson, and V. K. Dorai, "Management of multicriteria inventory classification," Math. Comput. Model., vol. 16, pp. 71-82, 1992.

[16] S. N. Bahagia, "Sistem Inventori," Bandung: Penerbit ITB, 2006.
Biografi Penulis

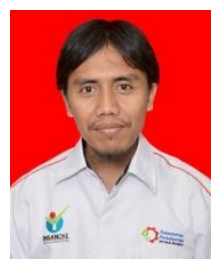

Nama Penulis

Eko Pratomo

Lulus pendidikan Sarjana pada Jurusan Teknik Kimia Fakultas Teknik Universitas Diponegoro tahun 2007. Penulis menyelesaikan program Pasca Sarjana pada Jurusan Teknik dan Manajemen Industri Institut Teknologi Bandung pada tahun 2014. 